\title{
Is smallpox a hazard in church crypts?
}

\author{
P J BAXTER, ' ANN M BRAZIER, ${ }^{2}$ SUSAN E J YOUNG ${ }^{3}$ \\ From the Employment Medical Advisory Service (London North Region),' Health \& Safety Executive, Barking, \\ Essex 1G11 8HF, Health \& Safety Executive, ${ }^{2}$ Bootle, Merseyside L20 3QZ, and Communicable Disease \\ Surveillance Centre, ${ }^{3}$ London NW9 5EQ, UK
}

The World Health Organisation (WHO) declared smallpox to be eradicated and vaccination no longer necessary in 1980 but doubts have remained about the long term viability of smallpox virus on well preserved corpses, especially if buried in permafrost. ${ }^{2}$ Recently, exhumation work in a London church crypt led to a reappraisal of the hazard in handling corpses buried at a time when smallpox was endemic in Britain.

\section{Background and description}

The church is of outstanding architectural importance and essential renovation work required the clearing of coffins from the crypt followed by cremation and reinterment of any remains. Burials in the crypt had taken place between 1729 and 1856 when it is estimated from the parish bills of mortality that perhaps $5-10 \%$ of deaths could have been from smallpox. The cool dry conditions in the crypt contributed to the preservation of the wooden coffins, many of which had sealed, intact lead linings and were therefore likely to contain well preserved corpses. As the exhumation work was to be performed by a team of archaeologists directed by palaeontologists, the Health \& Safety Executive (HSE) was asked to advise on the health precautions to be adopted for:

Phase 1 The moving of decayed coffins and the scientific examination of their human remains.

Phase 2 The internal examination of intact coffins containing well preserved corpses.

The WHO and the UK Advisory Committee on Dangerous Pathogens (ACDP) informed HSE that, although the risk was remote, survival of virus on the preserved skin of a smallpox victim interred in the crypt over 100 years ago could not be excluded. A detailed method statement was therefore prepared in collaboration with the local medical officer for environmental health that included basic hygiene precautions and medical surveillance but not vaccination, for the work which did not include the opening of intact coffins (phase 1). The clearance and scientific

Accepted 11 May 1987 work proceeded uneventfully for five months until in April 1985 three archaeologists believed that when they were examining the contents of a decayed wooden coffin they had uncovered, attached to a skeleton, a piece of desiccated skin bearing smallpox lesions. The archaeologists followed previously laid down procedures and immediately stopped work and reported their findings to HSE. On the advice of the Department of Health and Social Security the three archaeologists, who had all been vaccinated in childhood, agreed to be urgently revaccinated after the potential risks had been explained. In addition, under appropriate precautions, a sample of the suspicious material was collected and despatched to the WHO smallpox collaborating centre at the Centers for Disease Control in Atlanta, USA, for tests. No viable smallpox virus was found. The disinterment was subsequently resumed after the ACDP had advised that entry to the crypt be restricted to vaccinated individuals only. During the course of further work partially preserved skin was present on a proportion of corpses; about 60 were examined by one of us (SY) but no lesions suggestive of smallpox were found.

\section{Discussion}

The survival time of smallpox virus in preserved infected scabs has not been adequately documented, ${ }^{1}$ but viable virus was isolated from scabs kept in envelopes within a laboratory cupboard for up to 13 years when testing was discontinued. ${ }^{3}$ Most authorities believe that in the presence of moisture-for example, in earth burials-smallpox virus is unlikely to remain viable for long, and no more than one to two years even in exceptional conditions (J H Nakano, personal communication). Survival of the virus within scabs on the preserved skin of smallpox victims buried in permafrost or in dry cool crypts, however, could be much longer.' In the absence of reliable survival data some experts have advised the routine vaccination of archaeologists who might handle well preserved corpses. $^{2}$

In the initial phase of work vaccination was not 
recommended because the risk of serious complications from vaccination to the individuals and their contacts, though low, was believed to outweigh the risk of infection. The finding of suspicious remains led: to a rapid reversal of this decision because the potential infective risk to the workers could be ruled out only after an inevitable delay was incurred while comprehensive laboratory testing of the material (electron microscopy, culture, and DNA studies) was completed, by which time vaccination may have no longer been effective.

Numerous churches with burial crypts exist in Britain and authorised exhumations are not uncommon, but the detailed examination of the contents of this crypt for anthropological research increased the likelihood of exposure to possibly infected cadaverous material. No evidence of the survival of smallpox virus was found at this crypt where readily accessible preserved skin was subject to detailed examination for suspicious looking lesions. The cause of death of each of the deceased had not been originally recorded, however, so although our findings are reassuring they provide only limited evidence on the duration of survival of smallpox virus.

The HSE has prepared general guidance on disinterment procedures and we recommend that before crypt work is undertaken the state of the coffins and any visible remains are carefully assessed by medical and safety experts who have themselves been recently vaccinated so that recommendations may be made on a case by case basis. Routine vaccination is not envisaged but this type of work should be restricted to previously vaccinated individuals who do not suffer from any medical contraindication to revaccination should it become necessary, as in the incident described above. In the past mass vaccination would have limited the risk of smallpox infection in exhumation work. Now that vaccination has been discontinued in the general population the risk of reintroducing smallpox, however remote, should be carefully evaluated whenever exhumation work is being planned.

We acknowledge the help of numerous colleagues and other experts who advised us over the exhumation work and the preparation of this paper. We thank Dr J H Nakano and the Centers for Disease Control, Atlanta, USA, for performing the viral studies and Mr A D Mason and the archaeologists for their cooperation.

Requests for reprints to: Dr Peter Baxter, Department of Community Medicine, University of Cambridge, Fenner's, Gresham Road, Cambridge CB1 2ES.

\section{References}

1 Meers PD. Smallpox still entombed? Lancet 1985;i:1103.

2 Zuckerman AJ. Palaeontology of smallpox. Lancet 1984;ii:1454.

3 Wolff HL, Croon JJAB. Survival of smallpox virus (Variola minor) in natural circumstances. Bull WHO 1968;38:492-3. 